\title{
EFFECT OF GOOD HYGIENE SANITATION AND PERSONAL HYGIENE DEPOT MANAGEMENT OF REFILL DRINKING WATER ON THE QUALITY OF DRINKING WATER REVIEWED FROM COLIFORM MOST-PROBABLE-NUMBER IN KEDIRI
}

\author{
Indasah \\ Post-Graduate Program, Public Health Sciences, Institute of Health Science, Stikes Surya Mitra Husada, Kediri, \\ Indonesia
}

\section{ABSTRACT}

\begin{abstract}
Drinking water is a basic human need and must meet health requirements. Drinking water depots are a means of filling drinking water which is in the process of processing raw water using treatment and sterilization system. Drinking water depots as providers of drinking water must also meet the requirements of sanitation hygiene. Personal hygiene management must also be maintained so that the water produced meets health requirements. The purpose of this study was to determine the effect of sanitation hygiene and personal hygiene management of refill drinking water depots on the quality of drinking water in terms of the Coliform Most Probable Number in Kediri. The research design used was analytic observational with cross sectional approach. The population of all refill drinking water depots in Kediri was 57. Using Simple Random Sampling, 50 refill drinking water depots in Kediri were involved in this study. Data were collected by check list, questionnaire and laboratory examination. The results showed that most (77\%) of the hygiene sanitation of the drinking water depot had fulfilled the requirements. The drinking water personal hygiene depot was mostly (85\%) good, and those who met the drinking water requirements were $70 \%$. The results of the hygiene feasibility analysis showed significant value of $0.000<0.05(R=0.935)$. It means that there was an effect of hygiene sanitation quality on the water quality in terms of the Coliform Most Probable Number. Whereas, the personal hygiene had significant value of $0.001<0.05(R=0.528)$, indicating that there was personal hygiene influence on water quality in terms of the Coliform Most Probable Number. The results of Logistic Regression test showed that there were effects of sanitation hygiene and personal hygiene management of refill drinking water depots on water quality in terms of Coliform Most Probable Number with a significance value $=0.000<a 0.05$. This shows that better sanitation hygiene and personal hygiene at refill drinking water depots is increasingly fulfilling water quality requirements in terms of Coliform Most Probable Number.
\end{abstract}

Keywords: Sanitation hygiene; personal hygiene manager of drinking water depots; water quality of Coliform MPN

ABSTRAK

Air minum merupakan kebutuhan pokok manusia dan harus memenuhi syarat kesehatan. Depot air minum adalah suatu sarana pengisian air minum yang dalam proses pengolahan air bakunya menggunakan sistem treatmentasi dan sterilisasi. Depot air minum sebagai penyedia air minum juga harus memenuhi syarat laik hygiene sanitasi serta personal hygiene pengelolanya juga harus terjaga agar air yang diproduksi memenuhi syarat kesehatan. Tujuan penelitian ini untuk mengetahui Efek laik hygiene sanitasi dan personal hygiene pengelola depot air minum isi ulang terhadap kualitas air minum ditinjau dari Coliform Most Probable Number di Kediri. Desain penelitian yang digunakan observasional analitik dengan pendekatan cross sectional. Populasi semua depot air minum isi ulang di kota kediri sebanyak 57, dengan teknik pengambilan sampel yaitu Simple Random Sampling didapatkan sebagian depot air minum isi ulang di kota kediri yaitu sebanyak 50. Data dikumpulkan dengan chek list, kuesioner dan pemeriksaan laboratorium. Hasil penelitian menunjukkan bahwa sebagian besar laik hygiene sanitasi depot air minum sudah memenuhi syarat sebanyak 77\%, personal hygiene depot air minum sudah baik sebanyak 85\% dan yang memenuhi syarat air minum sebanyak $70 \%$. Hasil analisis Laik hygiene menunjukkan nilai Sig 0,000<0,05 $(R=0,935)$ artinya ada pengaruh laik hygiene sanitasi dengan kualitas air ditinjau dari Coliform Most Probable Number. Sedangkan pada personal hygiene nilai Sig 0,001 <0,05 $(R=0,528)$ menunjukkan ada pengaruh personal hygiene dengan kualitas air ditinjau dari Coliform Most Probable Number. Hasil uji Regresi Logistik didapatkan hasil ada pengaruh laik hygiene sanitasi dan personal hygiene pengelola depot air minum isi ulang dengan kualitas air ditinjau dari Coliform Most Probable Number dengan nilai signifikansinya =0,000 < a 0,05. Hal ini menunjukkan bahwa semakin laik hygiene dan semakin baik personal hygiene pada depot air minum isi ulang maka semakin memenuhi syarat kualitas air ditinjau dari Coliform Most Probable Number

Kata kunci: Laik hygiene sanitasi; personal hygiene pengelola depot air minum; kualitas air MPN Coliform

Correspondence: Indasah, Post-Graduate Program in Public Health Sciences, Institute of Health Science, Stikes Surya Mitra Husada Kediri, Indonesia. Phone: 085334494394. E-mail: iin.dasyah@ yahoo.com

pISSN:2355-8393 • eISSN: 2599-056x • doi: http://dx.doi.org/10.20473/fmi.v54i4.10705

- Fol Med Indones. 2018;54:241-248 • Received 21 Mar $2017 \bullet$ Accepted 21 Sep 2017

- Open access under CC-BY-NC-SA license • Available at https://e-journal.unair.ac.id/FMI/ 


\section{INTRODUCTION}

Drinking water is a basic human need because $80 \%$ of the body consists of liquid. Considering this, the need for healthy water quality becomes absolute. This demand is growing along with the development of public knowledge. There is a tendency for people to fulfill the need for drinking water in practical, economical, and hygienic ways (Wahyulesmono 2008). Water is a chemical compound that is very important for the life of living creatures. The function of water for life cannot be replaced by other compounds. The main and very vital use of water for life is as drinking water. However, according to Sujudi (2006), one of the existing clean water facilities is refill drinking water. Drinking water depots that do not meet health requirements can potentially be a transmission medium for various diseases. Chronologically, it can be explained through the epidemiological triangle in which the pathogen (causative agent) of the disease enters the body through the portal of entry and infects vulnerable hosts. Etiological pathogens (bacteria, viruses, worms, chemicals, substances of animals, plants or other factors) can be spread through media (reservoirs), such as humans, animals, conditions or certain environmental substances, such as food, feces or water and others (Timmreck 2005). These environmental substances include drinking water depots. Therefore, according to the recommendations of the Ministry of Health of Republic of Indonesia (2006), drinking water depots must meet health requirements, or having "health feasibility".

Considering this as an effort to reduce the incidence of infectious diseases, preventive measures should be pursued. One of them is through the management of quality drinking water refill depots. The quality of the drinking water depot must refer to the test standards regulated by Minister of Health Regulation No.416/ MenKes/Per/IX/1990 concerning Water Quality Requirements and Supervision and KepMenKes No. 907/ MenKes/SK/VII/2002 concerning Terms and Supervision of Drinking Water Quality (Wahyulesmono 2008). These conditions include bacteriological, chemical and radioactive requirements. Specifically for bacteriological requirements, there are several indicators that must be fulfilled, including Escherichia coli or Fecal coli or Total Coliform, in which the amount per $100 \mathrm{ml}$ sample should be 0 (zero). If the water quality of drinking water depots does not meet health requirements, this has the potential to have an impact on infectious diseases, especially those that can be transmitted through water, such as diarrhea, thyphoid, cholera, dysentery, skin diseases etc.

The lack of fulfillment of health requirements (bacteriological quality of drinking water) can be influenced by a variety of factors, ranging from water sources, processing, filter tubes, micro filters, water supply pump and pipe equipment, sterilization/disinfection equipment, bottle/gallon washing, bottle/gallon filling, operator, or the presence animals such as of rats/flies and cockroaches, as well as other conditions. Ideally, all of these factors meet the requirements called "sanitary hygiene feasibility". If these conditions do not meet the requirements, it can affect the quality of drinking water produced. One indicator can be seen from the numbers of Coliform Most Probable Number (KepMenKes Number 907/MenKes/SK/2002, page 16-17).

The presence of refill drinking water depots continues to increase in line with the dynamics of community needs for quality drinking water which is safe for consumption. Since it is cheaper, not all refill drinking water depots are assured of the condition of their products. The study of 120 refill drinking water depot samples from 10 major cities in Indonesia (Jakarta, Bogor, Tangerang, Bekasi, Cikampek, Semarang, Yogyakarta, Surabaya, Medan, and Denpasar) had become public attention because in some samples it was found about $16 \%$ were contaminated with Coliform bacteria. This indicates the poor quality of sanitation in refill drinking water depots. Escherichia coli bacteria are the microbiological parameters. The results of Asfawi's (2009) study of factors related to bacteriological quality of refill drinking water in Semarang showed that the hygiene conditions of drinking water depot workers (21 persons or $42.9 \%$ ) were mostly in low level category. This was because the workers did not always wash their hands before serving consumers. Whereas, in terms of sanitation conditions for drinking water depots, there were 18 samples $(36.7 \%)$ that did not meet health requirements. This was because, among others, the drinking water depot was in polluted area and the condition of the building was dirty.

The owner of the drinking water depot is the most responsible person in the business. Therefore, the owner must understand the hygiene of drinking water depots sanitation. This is important for they can understand properly and apply good production methods, so that the community is not harmed by the circulation of drinking water from the depots that do not meet health requirements. The owner must also supervise sanitation hygiene at each stage that is considered critical so that the safety and feasibility of drinking water can be guaranteed.

\section{MATERIALS AND METHODS}

This was a cross sectional study with observational design that emphasized the time of measurement/ 
observation of independent and dependent variables only once at a time. The population in this study were 57 refill water depots in Kediri. The samples in this study were 50 depots involved using simple random sampling. Instruments used in this study were questionnaire sheets and observation checklist. This study used logistic regression data analysis test. The error rate was determined as $\mathrm{a}=0.05$.

\section{RESULTS}

Raw water depot for drinking water in Kediri originated from $94.6 \%$ of springs and $5.4 \%$ from groundwater using their own drill. There were 31 male $(62 \%)$ and 19 female $(38 \%)$ respondents. There were $50 \quad(58 \%)$ respondents aged $>35$ years, 0 (zero) respondent aged $<20$ years, and $21(42 \%)$ respondents aged 20-35 years. Based on education level of 50 respondents, 25 (50\%) were graduated from senior high school, 6 (12\%) from elementary school, 11 (22\%) from junior high school, and $8(16 \%)$ had bachelor degree.

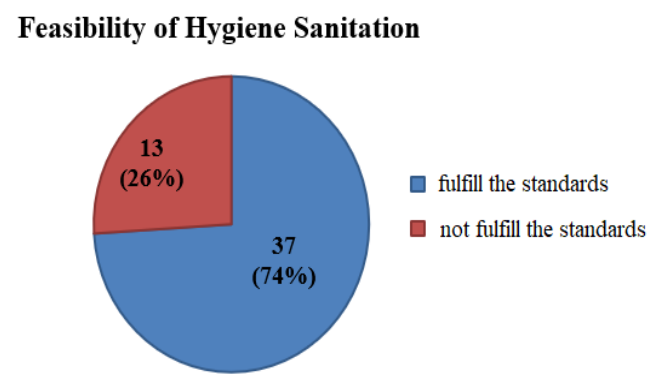

Fig. 1. Improved hygiene sanitation of refill drinking water depots in Kediri.

\section{Characteristics of hygiene sanitation feasibility}

Fig. 1 shows that of the 50 refill drinking water depots, $27(74 \%)$ depots meet the standards of sanitation hygiene, while those that do not meet sanitation requirements are $13(26 \%)$.

\section{Personal hygiene characteristics}

Fig. 2 shows that of the 50 refill drinking water depots, $41(82 \%)$ operators of refill drinking water depots have good personal hygiene, and those who have sufficient personal hygiene are as many as $9(18 \%)$, while those with deficient personal hygiene are 0 (zero).

\section{Characteristics of Coliform Most Probable Number content}

Fig. 3 shows that from 50 refill drinking water depots, those that fulfilled the requirements of the Coliform
Most Probable Number content in drinking water are 35 samples $(70 \%)$, while those that do not meet the requirements are $15(30 \%)$.

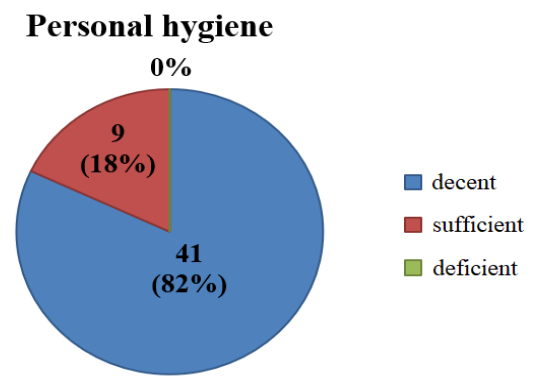

Fig. 2. Personal hygiene depot for refill drinking water in Kediri.

\section{The results of the hygiene sanitation feasibility analysis with the number of Coliform Most Probable Number}

Table 1 shows that most sanitation hygiene measures have met the requirements and the amount of the Coliform Most Probable Number content in water of 35 samples also meet the drinking water requirements. The results of the analysis showed that there was tendency to increasingly meeting the sanitary hygiene requirements as the water quality requirements also increased and vice versa.

In order to prove the significance of the relationship tendency, a test with the Phi efficiency test was carried out. Approx. Sig of $0.000<0.05(\mathrm{R}=0.935)$ was obtained, which means that the relationship between feasible hygiene and refill drinking water depots with drinking water quality was significant. The relationship was categorized as very strong ( $\mathrm{R} 0.935)$, indicating that the more fulfilling the hygiene depot sanitation to eligibility requirements, the more the water meeting the quality requirements in terms of the Coliform Most Probable Number content.

\section{Personal hygiene analysis results with the Coliform Most Probable Number content}

Table 2 shows that Coliform Most Probable Number content in water has met the drinking water requirements and that most personal hygiene is good in 33 (94\%) respondents. Based on the analysis, there seemed to be a tendency for the better personal hygiene. The better the personal hygiene, the better the water quality requirements, and vice versa. In order to prove the significance of the relationship tendency, a test with the Phi Efficiency test was carried out. Approx. Sig 0.001 $<0.05(\mathrm{R}=0.528)$ was obtained, meaning that the 
relationship between the personal hygiene depot of refill drinking water and drinking water quality was significant. The relationship was categorized as very strong $(\mathrm{R}=0.528)$, meaning that the better the personal hygiene depot of drinking water, the better the water quality in terms of the Coliform Most Probable Number content.

\section{Regression analysis results}

To find out the effect of sanitation and personal hygiene feasibility of the operators of the depots on drinking water quality in terms of Coliform Most Probable Number, a statistical test was carried out using logistic regression tests with $\mathrm{p}=0.000<0.005$. It means that there was a viable effect of sanitation hygiene and personal hygiene management of the depots on drinking water quality in terms of the Coliform Most Probable Number content in Kediri. Simultaneous logistic regression test results obtained $\mathrm{p}=0.000, \mathrm{p}<0.05$. It means that there was an effect of sanitation hygiene and personal hygiene management on refill drinking water depots with water quality in terms of the Coliform Most Probable Number content in Kediri
Most Probable Number Coliform Content

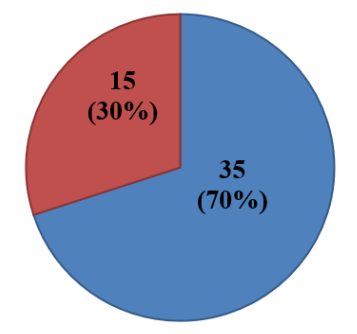

$\square$ fulfill the standards

$\square$ not fulfill the standards

Fig. 3. Coliform Most Probable Number contents of drinking water at refill drinking water depots in Kediri.

In the feasibility of hygiene sanitation variables, analysis with logistic regression test obtained sig value $=0.998$, sig $>0.05$. It means there was no relationship between hygiene sanitation feasibility and the content of Coliform Most Probable Number. Whereas, the personal hygiene variables obtained sig $=0.999$, sig $>0.05$, which means that there was no relationship between personal hygiene and the Coliform Most Probable Number content.

Table 1. Distribution of good hygiene sanitation to the number of Coliform Most Probable Number at refill drinking water depots in Kediri

\begin{tabular}{ccccccc}
\hline \multirow{2}{*}{$\begin{array}{c}\text { Feasibility of Hygiene } \\
\text { Sanitation }\end{array}$} & \multicolumn{3}{c}{ Coliform Most Probable Number } & \multicolumn{2}{c}{ Total } \\
\cline { 2 - 6 } & $\mathrm{N}$ & $\%$ & $\mathrm{~N}$ & $\%$ & $\mathrm{~N}$ & $\%$ \\
\cline { 2 - 6 } & 13 & 86.7 & 0 & 0 & 13 & 26.0 \\
Fulfilling & 2 & 13.3 & 35 & 100.0 & 37 & 74.0 \\
Not fulfilling & 15 & 100.0 & 35 & 100.0 & 50 & 100.0 \\
Total & Approx.Sig $=0.000<0.05(\mathrm{R}=0.935)$ \\
\hline
\end{tabular}

Table 2. Distribution of personal hygiene in the content of the Coliform Most Probable Number Most Probable Number at refill drinking water depots in Kediri

\begin{tabular}{|c|c|c|c|c|c|c|}
\hline \multirow{3}{*}{ Personal Hygiene } & \multicolumn{4}{|c|}{ Coliform Most Probable Number } & \multirow{2}{*}{\multicolumn{2}{|c|}{ Total }} \\
\hline & \multicolumn{2}{|c|}{ Fulfilling } & \multicolumn{2}{|c|}{ Not fulfilling } & & \\
\hline & $\mathrm{N}$ & $\%$ & $\mathrm{~N}$ & $\%$ & $\mathrm{~N}$ & $\%$ \\
\hline Deficient & 0 & 0 & 0 & 0 & 0 & 0 \\
\hline Sufficient & 7 & 46.7 & 2 & 5.7 & 9 & 18.0 \\
\hline Decent & 8 & 53.3 & 33 & 94.3 & 41 & 82.0 \\
\hline Total & 15 & 100.0 & 35 & 100.0 & 50 & 100.0 \\
\hline
\end{tabular}

Table 3. Simultaneous logistic regression test

\begin{tabular}{lccc}
\hline \multicolumn{1}{c}{ Variables } & Sig. value & R-Square & Simultaneity \\
\hline Feasibility of Hygiene & 0.998 & 0.850 & 0.000 \\
Sanitation & 0.999 & & \\
Personal Hygiene & & & \\
\hline
\end{tabular}


If these variables were concurrently tested, the results would affect the content of Coliform Probable Number which might reach a value of $85 \%$.

\section{DISCUSSION}

\section{Feasibility of hygiene sanitation refill drinking water depots}

The results of the study showed that the refill drinking water depots mostly had met the hygiene standard, which comprised 37 (74\%) out of a total of 50 drinking water depots. Whereas, drinking water depots that did not meet the eligibility for Hygiene Sanitation requirements were $13(26 \%)$.

Drinking water depots are said to be eligible if they meet sanitary hygiene requirements, including water sources, processing, filter tubes, micro filters, water supply and pumping equipment, sterilization or disinfection equipment, the way of washing bottles or gallons, the way of filling bottles or gallons, operators, preserving from mice, flies and cockroaches, requirements for floors, walls and ceilings, lighting and other activities. All aspects must be in healthy condition or in other words in sanitary conditions.

Drinking water depots that do not meet the requirements are caused by filter micro factors that have exceeded the service life, which has been determined by the manufacturers (factories that make) the micro filters. According to the results of the study, it was known that the micro filters used by drinking water depots had expired because the life-time provisions were only for 25,000 liters. After the calculation was done, it was used for more than 30,000 liters. Likewise, based on sterilization equipment, which were ozone or ultra violet, there were 11 depots that had equipment that could not function to kill germs effectively. Another reason was that the depots did not provide samples of the drinking water products. This is in accordance with the regulation of the Ministry of Health of Republic of Indonesia (2006) that in every drinking water depot there must be samples of drinking water products.

Most of the depots were included as fulfilling the hygiene and sanitation feasibility requirements because they had used raw water that was feasible as a source of water for drinking water refill. The transport vehicle has also fulfilled the health requirements because it was a vehicle with special tank equipped with a permission to transport. The process has used water reservoir protected from sunlight. Besides, the material used had met the health requirements. Pumping equipment, pipe distribution, sterilizers, bottle washing and water filling also met health requirements. The handlers/operators had maintained personal hygiene even though they did not yet have a certificate but has attended a sanitation depot course for drinking water. The places were clean with floors, walls, strong ceilings with bright lighting. The need for access to toilets already existed, and in general, the environmental conditions were clean and neatly arranged. This was supported by the fact that all drinking water depots had received counseling from the Health Office.

\section{Operators' personal hygiene of refill drinking water depots}

The results showed that most personal hygiene was good, which is found in $33(94 \%)$ respondents. Whereas, the results of cross tabulation showed that most of the respondents was male, comprising 29 respondents (70.7\%). Most of the respondents aged $>35$ and the personal hygiene was good in 22 respondents $(53.7 \%)$. Whereas, there were $22(53.7 \%)$ respondents with high school education with good personal hygiene.

Personal hygiene is an action to maintain one's hygiene and health for physical and psychological well-being. Personal hygiene aims to enable humans to maintain their own health, enhance and improve health values, and prevent illness. The goals of personal hygiene include; (1) maintaining health by washing hands, brushing teeth, bathing, dressing cleanly, (2) practicing a healthy and clean life; (3) causing a sense of comfort, fresh feeling, eliminating fatigue; and (4) maintaining skin condition.

Most respondents already have good personal hygiene because to maintain the quality of drinking water, both water sanitation and personal hygiene must also be maintained to prevent the spread of bacteria due to the low quality of physical health and personal hygiene of the depot operator. Good depot operators always pay attention to their personal hygiene and environment to be able to improve the quality of drinking water they manage.

\section{The content of the Coliform Most Probable Number in refill drinking water depots}

The results showed that the content of Coliform Most Probable Number in refill drinking water depots that met the requirements were $35(70 \%)$ out of the total 50 depots. Whereas, the content of the Coliform Most Probable Number that did not meet the requirements was $15(30 \%)$. The quality of drinking water for refill drinking water depots was said to fulfill health requirements if it was in accordance with the Minister of Health Decree No.907 of 2002 concerning Require- 
ments and Supervision of Drinking Water Quality (Ministry of Health of Republic of Indonesia 2006). In accordance with the Decree of the Minister of Health, the quality of drinking water must meet the requirements of physics, chemistry and bacteriology, as well as radioactivity. The bacteriological requirements has several indicators, including Escherichia coli or Fecal coli and the Total Coliform Most Probable Number number per $100 \mathrm{ml}$ should be 0 (zero) (Sujudi 2006).

The majority of refill drinking water depots had water quality that met health requirements because the water sources used were selected from raw water from mountain water far from sources of pollution or drilling with very deep groundwater extraction. Besides, it was also supported by an adequate water management system from the time of extraction using closed hygiene and transportation materials to minimize bacterial contamination. The water processing system had used very small (micron) diameter filter made of food grade material and there was more than one micro filter $(\mu)$ with a tiered size. These conditions of bacteria-free were maintained until the consumption period with good personal hygiene from the handler. Besides, ozonation was still functioning properly.

As for refill drinking water depots whose water quality did not meet health requirements, it may be caused by various factors that can reduce water quality. Observation showed that there were still micro filters and sterilization equipment that did not meet health requirements. There were 13 refill water depots whose micro filters had exceeded their usage time and the sterilization equipment had been ineffective in killing germs. This had an impact on the results of laboratory tests which showed that the Coliform Most Probable Number content per $100 \mathrm{ml}$ of water was more than 0 (zero).

\section{Effects of sanitation feasibility on water quality viewed from the Coliform Most Probable Number content}

The results of the analysis showed that the Sig value was 0.000 , sig<0.05. This means that there was relationship between hygiene and sanitation feasibility and water quality in terms of the Coliform Most Probable Number content. With the value of $\mathrm{R}=0.935$, it means that the more the depots fulfilling the hygiene sanitation feasibility requirements, the more they met the water quality requirements in terms of Coliform Most Probable Number content. The results of the study revealed that most of the depots that met the hygiene standard were 37 depots $(74 \%)$ out of a total of 50 depots. Whereas, the content of Coliform Most Probable Number in refill drinking water depots had met the requirements were $35(70 \%)$ of a total of 50 drinking water depots. According to Athena et al (2006), bottled drinking water was water that underwent a process of purification either by ultraviolet, ozonation or both by filtration. This made clean water can be used for various purposes.

There was a relationship between hygiene and sanitation with the Coliform Most Probable Number because refill drinking water depots had implemented sanitary hygiene in accordance with health requirements so they can break the chain of bacterial spread in the water. It can also prevent contamination of the water so that there were no bacteria in the water after going through filters and ozone or ultra violet sterilization. In general, refill water treatment system can be said to be effective if it can reduce the number of Coliform Most Probable Number germs in the water so that the final treatment can get water quality that met the requirements. It should not be more than 0 and suitable for consumption for community.

\section{Personal hygiene effects of refill drinking water depot managers on water quality in terms of the Coliform Most Probable Number content in Kediri}

Based on the analysis, it was found that the Sig was 0.001 , sig $<0.05$. It means that there was relationship between personal hygiene management of drinking water depot refills with the content of the Coliform Most Probable Number. With an $\mathrm{R}$ value of 0.528 , it means that the better the personal hygiene of the depot operator, the more it met the requirements of water quality in terms of the Coliform Most Probable Number content. The results of the study showed that most personal hygiene was good in 33 (94\%) respondents. Whereas, the depots that met the requirements of Coliform Most Probable Number content were 35 (70\%).

\section{CONCLUSION}

The more feasible hygiene and the better personal hygiene in refill drinking water depots, the more qualified the water quality in terms of the Coliform Most Probable Number.

\section{REFERENCES}

Asfawi S (2004). Analisis faktor yang berhubungan dengan kualitas bakteriologis air minum isi ulang di tingkat produsen di kota semarang. An unpublished thesis. Semarang, Universitas Diponegoro

Athena, et al (2006). Pengertian air minum kemasan. Jakarta, EGC. 
Ministry of Health of Republic of Indonesia (1997). Peraturan Menteri Kesehatan republik Indonesia Nomor 416/Menkes/PER/IX/1997 tentang SyaratSyarat dan Pengawasan Kualitas Air. Jakarta, Departemen Kesehatan Republik Indonesia

Ministry of Health of Republic of Indonesia (2001). Peraturan Pemerintah Republik Indonesia Nomor 82 Tahun 2001 Tentang Pengelolaan Pencemaran Air dan Pengendalian Pencemaran Air. Jakarta, Departemen Kesehatan Republik Indonesia

Ministry of Health of Republic of Indonesia (2002). Keputusan menteri kesehatan republik Indonesia nomor 907/menkes/sk/vii/2002 tentang syarat-syarat dan pengawasan kualitas air minum. Jakarta, Departemen Kesehatan Republik Indonesia.

Ministry of Health of Republic of Indonesia (2006). Pedoman Pelaksanaan Penyelenggaraan Hygiene Sanitasi Depot Air Minum. Jakarta, Dirjen PPL

Sujudi (2006). Keputusan Menteri Kesehatan Republik Indonesia nomor 907/menkes/SK/vII/2006. Jakarta, Menkes RI

Timmreck T (2005). Epidemiologi suatu pengantar. Jakarta, Penerbit Buku Kedokteran EGC

Wahyulesmono (2008). Depot air minum. Available from http://wahyulesmana.wordpress.com 